\title{
Istraživanje utjecaja inhibitora na koroziju ugljičnog čelika u vodi s biocidom
}

\author{
I. Smoljko, ${ }^{*}$ L. Vrsalović, S. Gudić i K. Đaković
}

Sveučilište u Splitu, Kemijsko-tehnološki fakultet, Zavod za elektrokemiju i zaštitu materijala, Ruđera Boškovića 35, 21000 Split, Hrvatska

\author{
Sažetak \\ koroziju ugljičnog čelika u korozivnim vodenim otopinama. \\ Ključne riječi \\ Ugljični čelik, korozija, inhibitor, biocid, gravimetrijska i elektrokemijske metode
}

U ovom radu istražen je utjecaj komercijalnog inhibitora (Chemtec Fl30) na proces korozije ugljičnog čelika P235 u različitim vodenim otopinama; demineraliziranoj i/ili vodovodnoj vodi uz dodatak komercijalnog biocida (Chemtec BI01). Istraživanja su provedena gravimetrijskom metodom i elektrokemijskim metodama, dok je površina ispitivanog materijala analizirana pomoću optičkog mikroskopa. Analize pokazuju da inhibitor smanjuje brzinu korozije ugljičnog čelika u ispitivanim otopinama, ima visoku djelotvornost te da se može svrstati u anodne inhibitore. Također, uočeno je da inhibitor smanjuje opću i jamičastu

\section{Uvod}

Ugljični čelik se upotrebljava za izradu cijevi tlačnih cjevovoda za transport i distribuciju vode (vodoopskrba, navodnjavanje, hidroelektrane) te cjevovoda za odvod voda (odvodnja otpadnih voda i oborinskih voda), koji mogu biti s tečenjem sa slobodnim vodnim licem i povremeno pod tlakom. ${ }^{1,2}$ Tijekom životnog ciklusa cijevi od ugljičnog čelika izložene su različitim kemijskim, fizikalnim i biološkim utjecajima koji mogu uzrokovati njihovo korozijsko oštećenje. Posljedice navedenog mogu biti različiti materijalni i ekonomski gubitci; skraćenje vijeka trajanja industrijske i druge opreme, kvarovi i zastoji u radu, nesreće, smanjenje proizvodnog kapaciteta opreme, smanjenje kvalitete proizvoda, poskupljenje održavanje i dr. ${ }^{1}$ Kako bi se spriječilo korozijsko oštećenje konstrukcijskih materijala, proučavaju se korozijski procesi i nastoje se pronaći zaštitne metode.

Dosadašnja istraživanja pokazala su da korozija ugljičnog čelika ovisi o kemijskim i fizikalnim svojstvima čelika, o tipu i sastavu vode (voda za piće i kućanstvo, morska voda, demineralizirana voda, omekšana voda, dekarbonizirana voda, $\mathrm{pH}$, prisutnost iona, sadržaj organskih tvari, sadržaj otopljenog kisika i dr.) i o uvjetima u cjevovodu (brzina strujanja, temperatura, mikrobiološka aktivnost, primjena inhibitora korozije itd.). ${ }^{3-8}$

U atmosferi, u vodi i vodenim otopinama soli koje nisu inhibitori korozije, na površini ugljičnog čelika nastaje vlažna i rahla smjesa oksida, hidroksida i oksidhidrata dvovalentnog i trovalentnog željeza, tj. hrđa čiji se sastav može izraziti formulom $x \mathrm{Fe}_{2} \mathrm{O}_{3} \cdot y \mathrm{FeO} \cdot z \mathrm{H}_{2} \mathrm{O}$. Njezina boja varira od žute preko crvene i smeđe do crne. Navedeni proces obično napreduje kao opća korozija uz kisikovu depolarizaciju ili redukciju vodika (u anaerobnim uvjetima). ${ }^{1-7}$

*Autor za dopisivanje: izv. prof. dr. sc. Ivana Smoljko

e-pošta: ismoljko@ktf-split.hr
Degradaciju ugljičnog čelika izazivaju i mikrorganizmi i/ili produkti njihova metabolizma koji uzrokuju mikrobiološki poticanu koroziju (engl. microbially induced corrosion, MIC). ${ }^{8-12} \mathrm{U}$ svojem radu Flemming ${ }^{12}$ ističe ekonomsku važnost MIC-a te navodi podatak da je više od $20 \%$ ukupnih troškova uslijed korozije povezano s MIC-om. Kao primjer možemo navesti i velike gubitke i štetu na Transaljaškom naftovodnom sustavu (engl. Trans-Alaska Pipeline System) 2006. godine koji se pripisuju upravo MIC-u. ${ }^{13}$

Glavne vrste bakterija povezane s korozijom čelika su sulfat-reducirajuće bakterije, sulfid-oksidirajuće bakterije, željezo-oksidirajuće bakterije, mangan-oksidirajuće bakterije, kao i bakterije koje izlučuju organske kiseline i izvanstanične polimerne čestice. Ti mikroorganizmi na površini metala najčešće tvore kompleksne zajednice, tzv. biofilm koji utječe na elektrokemijske procese preko udruženih metabolizama. Posljedica međudjelovanja u biofilmovima može biti ubrzanje korozijskog procesa, ali i inhibicija korozije metala. ${ }^{14-18}$

$\mathrm{U}$ rashladnim postrojenjima mikroorganizmi, kao što su alge i bakterije (npr. željezo-oksidirajuće bakterije), mogu djelovati ne samo korozivno već mogu i smanjiti protočnost u cjevovodu. ${ }^{19-21}$ Mnoge bakterije raznih rodova mogu sudjelovati u biotransformaciji metalnih oksida u cjevovodima za tehnološku vodu ili vodu za piće. Pa tako bakterije iz rodova Crenothrix, Leptothrix, Siderocapsa, Thiobacillus, Ferrobacillus i druge oksidiraju otopljene Fe(II) ione u viševalentne oksihidrate, pri čemu priskrbljuju energiju potrebnu za život i rast. ${ }^{21-28}$ Oslobođenu energiju ti mikroorganizmi mogu iskoristiti za izgradnju svoje biomase od anorganskog otopljenog ugljika iz vode $\left(\mathrm{CO}_{2}\right)$ te svojim rastom u cijevima sužavaju profile cjevovoda. Željezo oksidirajuće bakterije sintetiziraju sluzavu tvar koja ima želatinoznu konzistenciju i smeđe je boje, a može poslužiti za rast drugih bakterija, pa može doći i do masovnog bakteriološkog onečišćenja u čitavoj vodovodnoj mreži. Također, rast tih bakterija na stjenkama cjevovoda može dovesti do 
Tablica 1 - Kemijski sastav ugljičnog čelika P235

Table 1 - Chemical composition of carbon steel P235

\begin{tabular}{|c|c|c|c|c|c|c|c|c|c|c|c|}
\hline \multicolumn{12}{|c|}{$w / \%$} \\
\hline C & $M n$ & $P$ & $S$ & $\mathrm{Si}$ & $\mathrm{Cu}$ & Mo & $\mathrm{Al}$ & $\mathrm{Cr}$ & $\mathrm{Ni}$ & Sn & $\mathrm{Fe}$ \\
\hline 0,056 & 0,45 & 0,015 & 0,01 & 0,21 & 0,171 & 0,019 & 0,027 & 0,037 & 0,062 & 0,012 & $\begin{array}{c}\text { ostatak } \\
\text { rest }\end{array}$ \\
\hline
\end{tabular}

korozije zbog kiseline proizvedene pri biološkoj oksidaciji željeza. ${ }^{20-28}$

Ugljični čelik, tj. konstrukcijske materijale od kojih su izrađeni cjevovodi potrebno je zaštiti od korozije. Zaštita čelika od korozije u raznim medijima kao što su otopine kiselina, otopine lužina, neutralne vodene otopine, nafta i dr. u velikoj mjeri ostvaruje se uporabom inhibitora korozije. ${ }^{29-32}$ Također, za sprječavanje razvoja mikroorganizama u vodi i drugim tekućinama u rashladnim i radnim sustavima dodaju se biocidni proizvodi, tj. biocidi. ${ }^{33,34}$

U ovom radu bit će prikazani rezultati istraživanja utjecaja komercijalnog inhibitora (Chemtec FI30) na proces korozije ugljičnog čelika P235 u različitim vodenim otopinama; demineraliziranoj i/ili vodovodnoj vodi uz dodatak komercijalnog biocida (Chemtec BI01). Istraživanja su provedena gravimetrijskom metodom i elektrokemijskim metodama (metoda mjerenja potencijala otvorenog kruga, metoda linearne polarizacije i potenciodinamička polarizacijska metoda). Površina ispitivanog materijala analizirana je pomoću optičkog mikroskopa pri različitim uvećanjima.

\section{Eksperimentalni dio}

Ispitivanja su provedena na uzorcima ugljičnog čelika oznake P235 kemijskog sastava prikazanog u tablici 1.

Mjerenja su provedena u otopinama sljedećeg sastava; otopina dobivena miješanjem demineralizirane vode i vodovodne vode u omjeru $50: 50 \mathrm{~s}$ biocidom, bez dodatka i uz dodatak inhibitora te u vodovodnoj vodi s biocidom, bez dodatka i uz dodatak inhibitora. Ispitivane otopine sadržavale su 15 ppm komercijalnog biocida (Chemtec BI01), a volumenska koncentracija komercijalnog inhibitora (Chemtec Fl30) iznosila je 1,5\%. Ispitivanja su provedena pri $20^{\circ} \mathrm{C}$.

\subsection{Gravimetrijska mjerenja}

U svrhu ispitivanja brzine korozije gravimetrijskom metodom iz cijevi od ugljičnog čelika izrezani su testni uzorci dimenzija $20 \times 40 \times 3 \mathrm{~mm}$. Uzorci su mehanički obrađeni brušenjem brusnim papirima granulacije 180, 280, 400, 600, 800 te 1000 rastućim slijedom. Zatim su odmašćeni u etanolu u ultrazvučnoj kupelji, nakon čega su intenzivno isprani destiliranom vodom, osušeni na sobnoj temperaturi te izvagani na analitičkoj vagi. Nakon pripreme uzorci su pojedinačno uronjeni u posude u kojima je uliveno $100 \mathrm{ml}$ ispitivanih otopina. Posude su bile hermetički zatvorene $480 \mathrm{~h}$ pri sobnoj temperaturi. Tijekom eksperimenta uzorci su fotografirani. Po završetku razdoblja izlaganja uzorci su izvađeni iz posuda i pozorno očišćeni u ultrazvučnoj kupelji u demineraliziranoj vodi, osušeni, a potom su izvagani. Također, poslije izlaganja mediju površina ispitivanog uzorka ugljičnog čelika analizirana je optičkim mikroskopom (MXFMS-BD, Ningbo Sunny Instruments co.) pri povećanju $40 \times$ te je fotografirana digitalnim fotoaparatom.

\subsection{Elektrokemijska mjerenja}

Za elektrokemijska ispitivanja korozijskog ponašanja ugljičnog čelika, od uzorka napravljena je elektroda oblika kvadra koji je bio s vanjskim krugom spojen preko bakrene žice te zaštićen sa svih strana, osim s jedne, akrilatnim materijalom (Polirepar S). Baza kvadra geometrijske površine $1,8 \mathrm{~cm}^{2}$ predstavljala je radnu površinu, tj. dio radne elektrode koji je bio u kontaktu s otopinom. Prije svakog slijeda elektrokemijskih mjerenja, koji se sastojao od stabilizacije elektrode na potencijalu otvorenog kruga $\left(E_{\mathrm{OK}}\right)$ zatim mjerenja linearne polarizacije i potom potenciodinamičkog mjerenja, radna površina elektrode je mehanički obrađena brušenjem brusnim papirima različite finoće od 180 do 1500, polirana suspenzijom za poliranje veličine čestica $0,05 \mu \mathrm{m}$, odmašćena etanolom u ultrazvučnoj kupelji $\mathrm{i}$ isprana demineralizranom vodom te postavljena $u$ elektrokemijski reaktor. U svim mjerenjima kao referentna elektroda upotrebljavana je zasićena kalomel elektroda (ZKE), koja je preko Luggin kapilare bila u kontaktu s radnom elektrodom, a kao pomoćna elektroda platina. Sva elektrokemijska mjerenja provedena su na računalom upravljanom potenciostatu/galvanostatu EG\&G PAR model 273A u otopinama navedenog sastava pri sobnoj temperaturi. Prije izvođenja mjerenja elektroda je stabilizirana na potencijalu otvorenog kruga tijekom 60 min. Mjerenja linearne polarizacije, tj. određivanja polarizacijskog otpo$\mathrm{ra}$, provodila su se u području potencijala $\pm 20 \mathrm{mV}$ od potencijala otvorenog kruga. Brzina promjene potencijala iznosila je $0,1 \mathrm{mV} \mathrm{s}^{-1}$. Potenciodinamička polarizacijska mjerenja provodila su se s brzinom promjene potencijala $0,5 \mathrm{mV} \mathrm{s}^{-1}$, u području potencijala od $-250 \mathrm{mV}$ prema $E_{\mathrm{OK}}$ do $600 \mathrm{mV}$ prema $E_{\mathrm{OK}}$. Nakon potenciodinamičkih polarizacijskih mjerenja površina ispitivanog uzorka ugljičnog čelika je bez naknadne obrade analizirana optičkim mikroskopom pri povećanju $100 \times$ te je fotografirana digitalnim fotoaparatom. 


\section{Rezultati i rasprava}

U prvom dijelu rada određivana je brzina korozije metodom gubitka mase. Gravimetrijska metoda se temeljila na mjerenju promjene mase uzorka ugljičnog čelika P235 nakon $480 \mathrm{~h}$ u zatvorenom sustavu u otopinama s biocidom bez dodatka i uz dodatak inhibitora. Tijekom i nakon te faze ispitivanja površina uzorka ugljičnog čelika je fotografirana digitalnim fotoaparatom.

Na slici 1 prikazane su fotografije površine ugljičnog čelika $\mathrm{u}$ otopini dobivenoj miješanjem demineralizirane vode i vodovodne vode u omjeru $50: 50 \mathrm{~s}$ biocidom snimljene tijekom 480 h izlaganja. Može se uočiti kako je nakon 48 h cijela površina uzorka prekrivena žućkasto-narančastim slojem korozijskih produkata. Također, oko uzorka čelika, po dnu posudice, može se vidjeti talog korozijskih produkata. Navedeno upućuje na slabu povezanost korozijskih produkata s površinom čelika. Usporedbom slika uzorka može se uočiti kako se s vremenom izlaganja ugljičnog čelika P235 povećava količina korozijskih produkata na njegovoj površini, ali i istaloženih na dnu posudice u otopini.
Nakon 480 h uzorak je izvađen iz otopine (slika 2a), potom je obrađen u demineraliziranoj vodi u ultrazvučnoj kupelji kako bi se uklonili slojevi korozijskih produkata a zatim osušen (slika $2 b$ ) i izvagan na analitičkoj vagi. Poslije vaganja površina ispitivanog uzorka ugljičnog čelika analizirana je optičkim mikroskopom pri povećanju $40 \times$ te je fotografirana digitalnim fotoaparatom (slika 2c). Ultrazvučnom obradom uzorka u demineraliziranoj vodi većinom su uklonjeni korozijski produkti. Na površini su zaostali korozijski produkti koji su bolje prianjali za površinu a bili su narančasto-crvene i sivo-crne boje (slika 2b). Pregledom optičkim mikroskopom može se zaključiti da na površini ugljičnog čelika P235 u ispitivanoj otopini dolazi do opće korozije.

Dodatak komercijalnog inhibitora u otopinu vodovodne vode i demineralizirane vode $(50: 50)$ i biocida uzrokuje znatne promjene ponašanja sustava, kao što se može vidjeti na slici 3. Površina uzorka nakon 48 h prekrivena je sivo-crnim slojem (slika 3a). Tijekom vremena izlaganja dolazi do zamućenja otopine a oko uzorka je uočen ta-
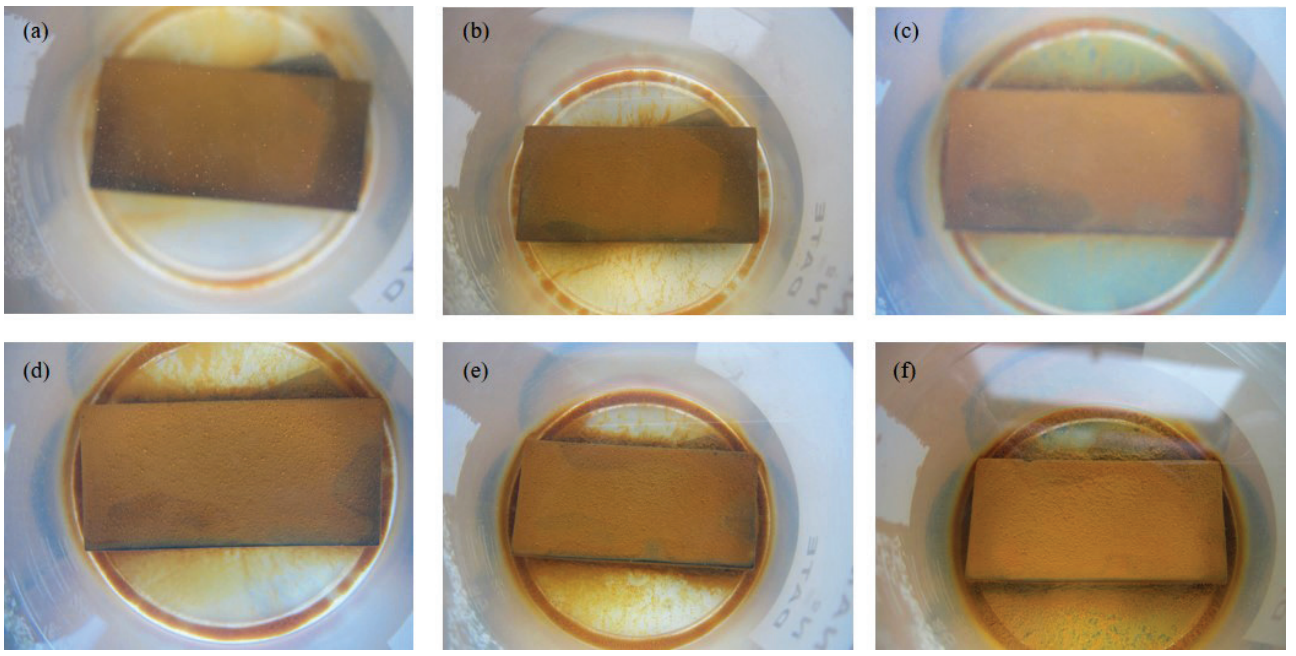

Slika 1 - Uzorak ugljičnog čelika P235 u otopini demineralizirane i vodovodne vode (50:50) i biocida nakon a) 48 h, b) 72 h, c) 144 h, d) 216 h, e) 312 h i f) $480 \mathrm{~h}$

Fig. 1 - P235 carbon steel sample immersed in solution of demineralised and tap water $(50: 50)$ with biocide after a) 48 h, b) 72 h, c) 144 h, d) 216 h, e) 312 h, and f) $480 \mathrm{~h}$
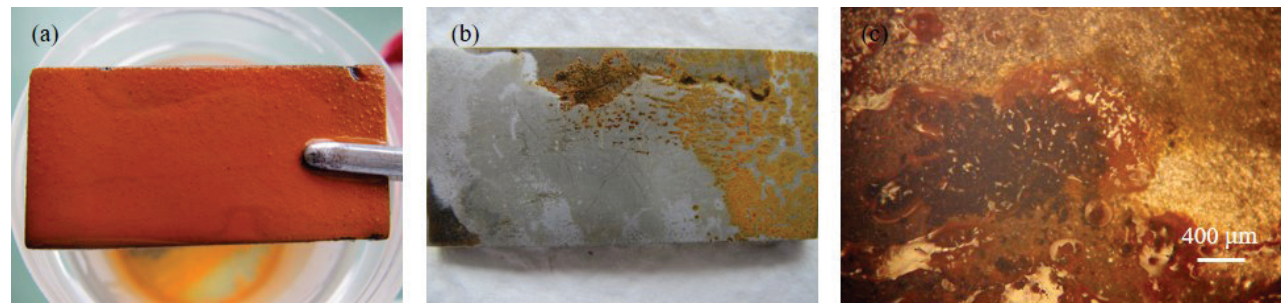

Slika 2 - Površina uzorka ugljičnog čelika P235 a) nakon vađenja iz otopine demineralizirane i vodovodne vode $(50: 50)$ i biocida, b) nakon ultrazvučnog čišćenja, c) snimljena pri povećanju $40 \times$

Fig. 2 - P235 carbon steel sample surface a) after being taken out from solution of demineralised and tap water $(50: 50)$ with biocide, b) after ultrasonic cleaning, c) taken at $40 \times$ magnification 
log sive boje koji s vremenom postaje sve tamniji i nakon 480 sati je gotovo crne boje (slika 3f).

Nakon 480 h uzorak je izvađen iz otopine (slika 4a) te se može vidjeti kako je većina površine uzorka prekriveno sivo-crnim slojem, najvjerojatnije slojem adsorbiranog inhibitora i produkata korozije. Ultrazvučnom obradom u demineraliziranoj vodi s površine uzorka uklonjeni su korozijski produkti. Neposredno nakon uklanjanja produkata korozije s površine ugljičnog čelika uzorak je osušen i izvagan na analitičkoj vagi. Vizualnim pregledom utvrđeno je da i uz dodatak inhibitora dolazi do opće korozije koja je uzrokovala potamnjene i hrapavost površine uzorka ugljičnog čelika (slika 4b). Navedeno je potvrđeno i analizom optičkim mikroskopom pri povećanju 40× (slika 4c).

Na slici 5 prikazan je uzorak ugljičnog čelika P235 uronjen u vodovodnu vodu s biocidom tijekom 480 h. Usporedbom slike 5 sa slikom 1 može se uočiti sličnost u ponašanju ugljičnog čelika u otopini vodovodne vode i demineralizirane vode (50:50) i biocida i vodovodne vode s biocidom. Naime, u obje otopine nakon $48 \mathrm{~h}$ cijela površina uzorka prekrivena je žućkasto-narančastim slojem korozijskih produkata. Nadalje, količina korozijskih produkata povećava se s vremenom, a kako je njihova adhezija s površinom slaba, dolazi do njihova odvajanja od površine i taloženja oko uzorka.

Na slici 6a) prikazan je uzorak ugljičnog čelika P235 nakon vađenja iz vode s biocidom, nakon ultrazvučne obrade u demineraliziranoj vodi (slika 6 b) te snimka površine povećane $40 \times$ nakon sušenja i vaganja uzorka (slika 6c). Analizom površine uzorka pomoću optičkog mikroskopska uočene su promjene morfologije površine uzorka. Utvrđena su lokalna korozijska žarišta što znači da se uz opću koroziju odvija i jamičasta korozija, najvjerojatnije zbog prisutnih kloridnih iona u vodovodnoj vodi.

Dodatak inhibitora u vodovodnu vodu s biocidom u potpunosti mijenja proces korozije ugljičnog čelika, što je vidljivo iz slike 7 . Nakon $72 \mathrm{~h}$ (slika $7 \mathrm{~b}$ ) po uranjanju u vodovodnu vodu, površina čelika je i dalje sjajna bez vidljivih korozijskih produkata na površini. S povećanjem vremena izlaganja dolazi do formiranja tamno sivih i crnih naslaga
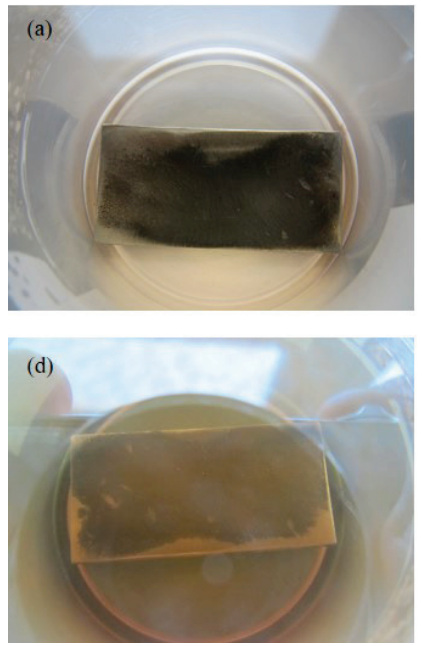
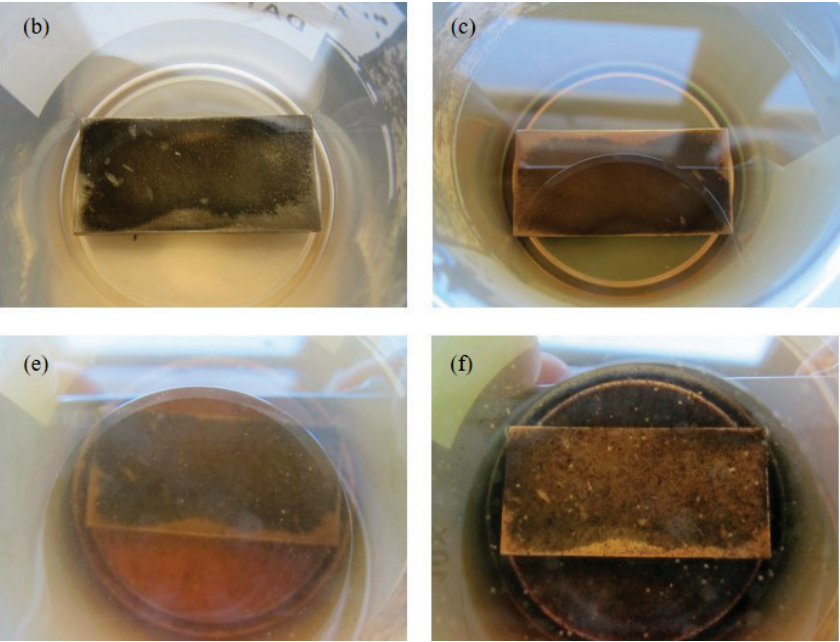

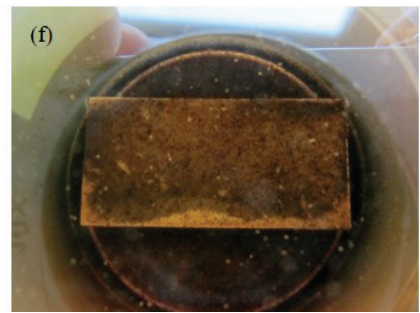

Slika 3 - Uzorak ugljičnog čelika P235 u otopini demineralizirane i vodovodne vode (50 : 50) i biocida uz dodatak inhibitora nakon a) 48 h, b) 72 h, c) 144 h, d) 216 h, e) 312 h i f) 480 h

Fig. 3 - P235 carbon steel sample immersed in solution of demineralised and tap water $(50: 50)$ with biocide and with addition of the inhibitor after a) 48 h, b) 72 h, c) 144 h, d) 216 h, e) $312 \mathrm{~h}$, and f) $480 \mathrm{~h}$
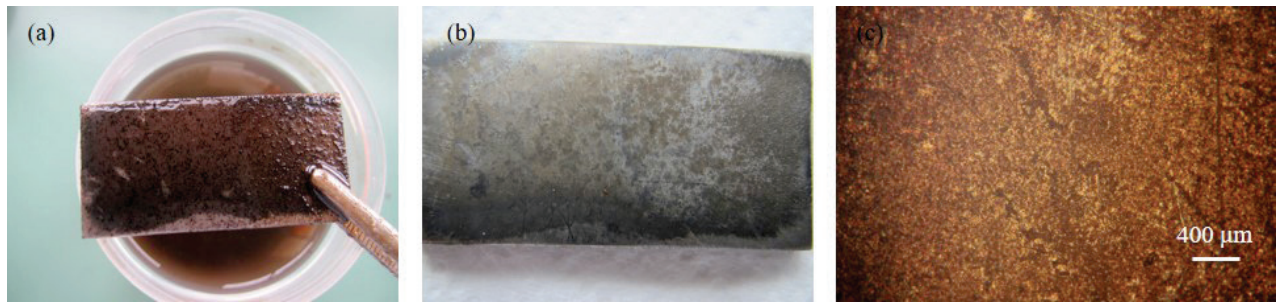

Slika 4 - Površina uzorka ugljičnog čelika P235 a) nakon vađenja iz otopine demineralizirane i vodovodne $(50: 50)$ i biocida uz dodatak inhibitora, b) nakon ultrazvučnog čišćenja, c) snimljena pri povećanju $40 \times$

Fig. 4 - P235 carbon steel sample surface a) after being taken out from solution of demineralised and tap water $(50: 50)$ with biocide and with addition of the inhibitor, b) after ultrasonic cleaning, c) taken at $40 \times$ magnification 

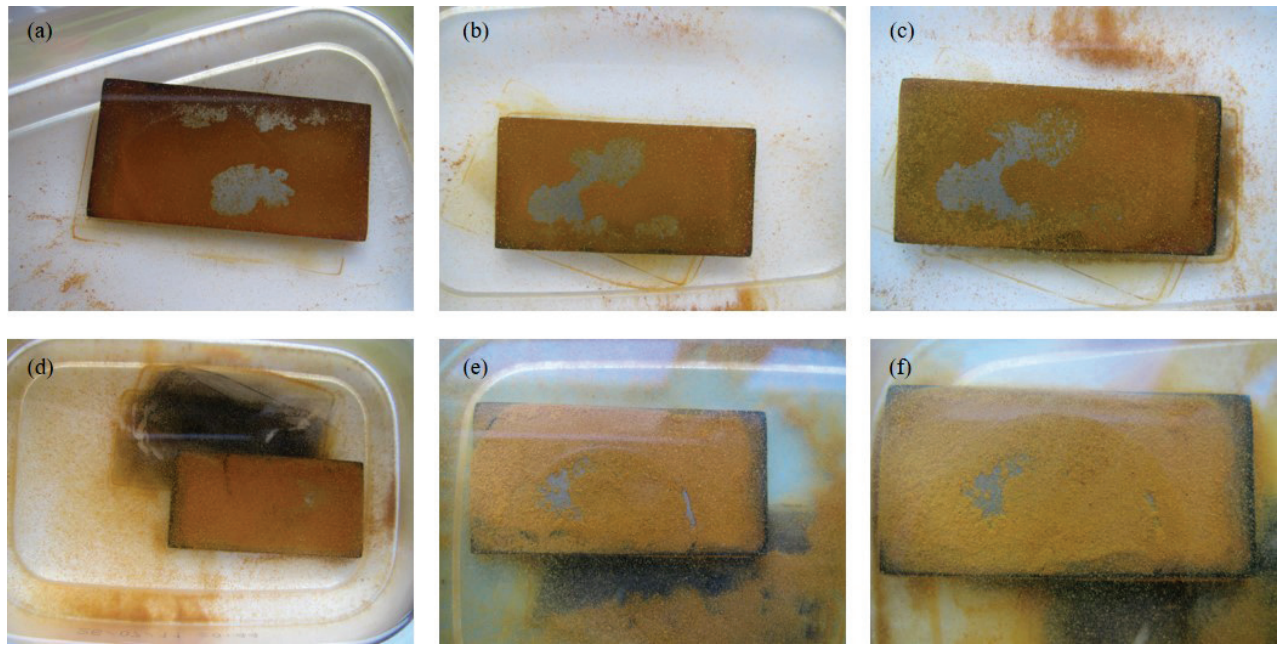

Slika 5 - Uzorak ugljičnog čelika P235 u vodovodnoj vodi s biocidom nakon a) 48 h, b) 72 h, c) $144 \mathrm{~h}$, d) $216 \mathrm{~h}$, e) $312 \mathrm{~h}$ i f) $480 \mathrm{~h}$

Fig. 5 - P235 carbon steel sample immersed in tap water with biocide after a) 48 h, b) 72 h, c) $144 \mathrm{~h}$, d) $216 \mathrm{~h}$, e) $312 \mathrm{~h}$, and f) $480 \mathrm{~h}$
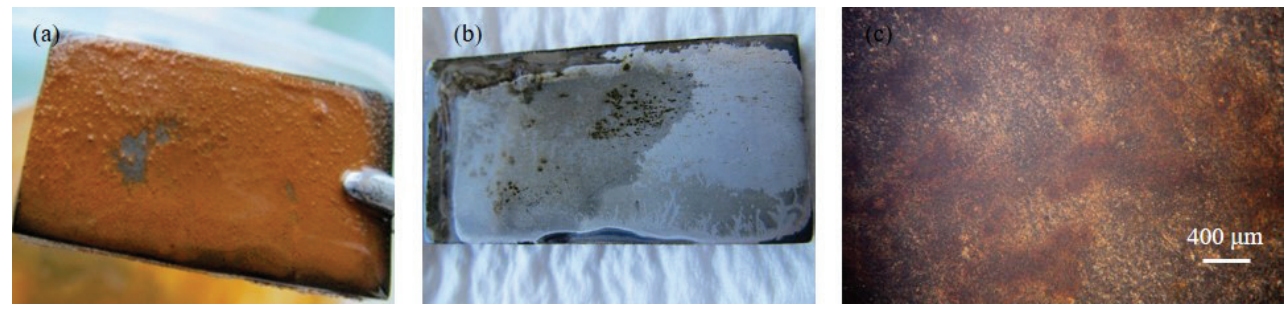

Slika 6 - Površina uzorka ugljičnog čelika P235 a) nakon vađenja iz vodovodne vode s biocidom, b) nakon ultrazvučnog čišćenja, c) snimljena pri povećanju $40 \times$

Fig. 6 - P235 carbon steel sample surface a) after being taken out from tap water with biocide, b) after ultrasonic cleaning, c) taken at $40 \times$ magnification
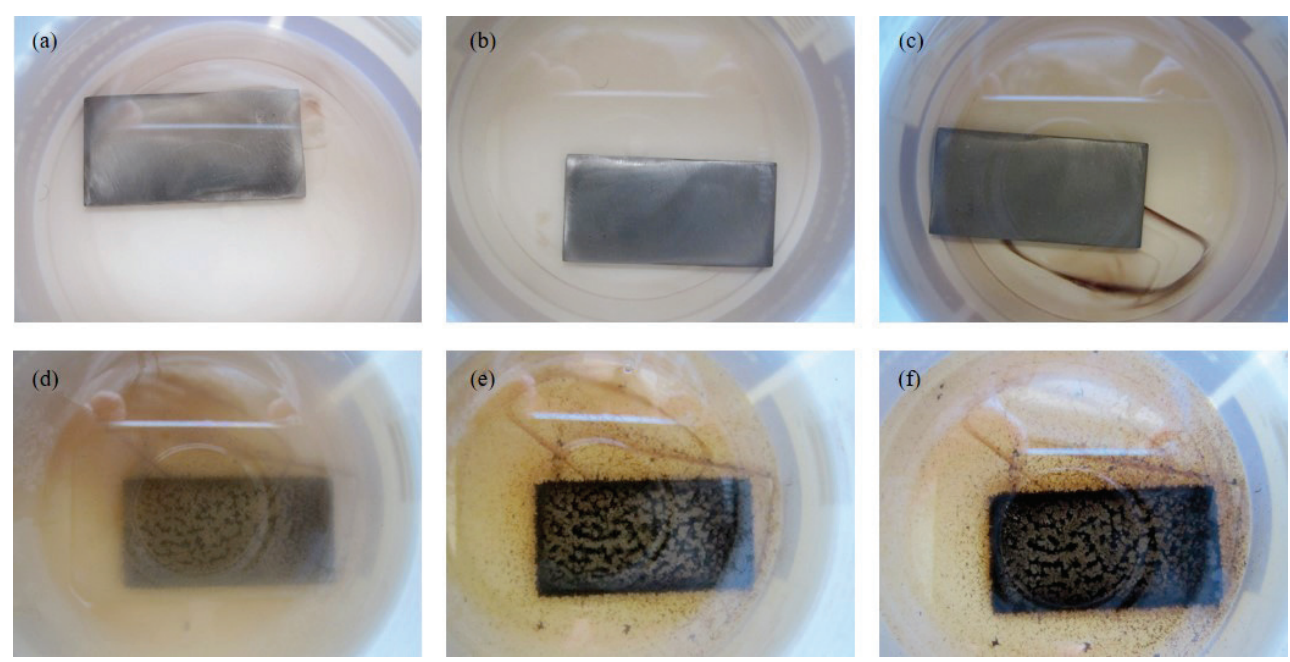

Slika 7 - Uzorak ugljičnog čelika P235 u vodovodnoj vodi s biocidom uz dodatak inhibitora nakon a) 48 h, b) 72 h, c) 144 h, d) 216 h, e) 312 h i f) 480 h

Fig. 7 - P235 carbon steel sample immersed in tap water with biocide and with addition of inhibitor after a) 48 h, b) 72 h, c) 144 h, d) 216 h, e) $312 \mathrm{~h}$, and f) $480 \mathrm{~h}$ 

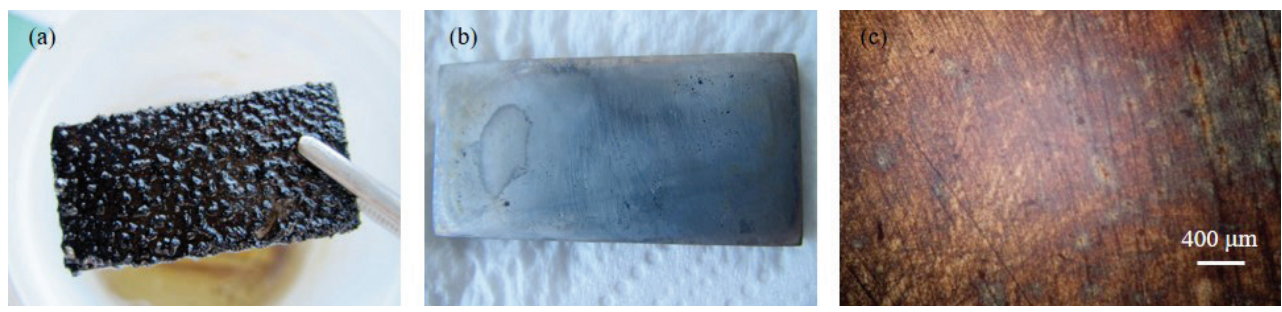

Slika 8 - Površina uzorka ugljičnog čelika P235 a) nakon vađenja iz vodovodne vode s biocidom uz dodatak inhibitora, b) nakon ultrazvučnog čišćenja, c) snimljena pri povećanju $40 \times$

Fig. 8 - P235 carbon steel sample surface a) after being taken out from tap water with biocide with addition of the inhibitor, b) after ultrasonic cleaning, c) taken at $40 \times$ magnification

na površini čelika, ali i tamnog taloga oko čeličnog uzorka. Najvjerojatnije se radi o adsorbiranom inhibitoru u kombinaciji s korozijskim produktima i biocidom.

Kao što se može uočiti na slici 8a), nakon vađenja iz otopine, uzorak je gotovo u potpunosti prekriven tamnim površinskim slojem koji je uspješno uklonjen dugotrajnijom obradom u demineraliziranoj vodi pomoću ultrazvučne kupelji (slika 8b). Nakon uklanjanja površinskog sloja vizualnim pregledom utvrđeno je da je površina uzorka djelomično ostala sjajna s malim brojem nasumce raspoređenih oštećenja. Navedeno je potvrđeno i analizom površine uzorka pomoću optičkog mikroskopska pri povećanju $40 \times$. Na osnovi iznesenog može se zaključiti da dodatak inhibitora smanjuje koroziju ugljičnog čelika u vodovodnoj vodi s biocidom.

U tablici 2 prikazane su vrijednosti promjene mase uzorka ugljičnog čelika dobivene vaganjem uzorka prije izlaganja otopinama te nakon izlaganja i uklanjanja produkata korozije. Vidljivo je da su nakon 480 h veći gubitci mase u vodovodnoj vodi s biocidom nego li u vodovodnoj vodi i demineraliziranoj vodi s biocidom. Navedeno upućuje na zaključak da prisutni ioni u vodovodnoj vodi uzrokuju veću korozivnost ugljičnog čelika. Dodatak inhibitora znatno smanjuje gubitak mase ugljičnog čelika u svim ispitivanim vodnim otopinama.

Gubitak mase sveden na jedinicu početne geometrijske površine izloženog materijala prava je mjera za napredovanje korozije, a brzina korozije izračunata je izrazom:

$$
v=\frac{\Delta m \cdot K}{A \cdot t \cdot \rho} \cdot 100 \mathrm{~mm} / \mathrm{god}
$$

u kojem je $\Delta m$ gubitak mase ispitivanog materijala $\mathrm{u} g, K$ konstanta koja iznosi 8760 , površina uzorka je $A \mathrm{u} \mathrm{cm}{ }^{2}, t$ je vrijeme izlaganja uzorka elektrolitu u h, dok je $\rho$ gustoća uzorka u $\mathrm{g} \mathrm{cm}^{-3}$. Iz odnosa brzine korozije bez inhibitora $\left(v_{0}\right)$ i s inhibitorom $\left(v_{\mathrm{i}}\right)$ izračunat je stupanj djelotvornosti inhibitora (z) prema sljedećem izrazu:

$$
z=\frac{v_{0}-v_{i}}{v_{0}} \cdot 100
$$

Iz tablice 2 vidljivo je da se dodatkom inhibitora znatno smanjuje brzina korozije ugljičnog čelika. Brzine korozije izračunate na temelju gubitka mase donekle su mjerodavne za ocjenu upotrebljivosti konstrukcijskog materijala zahvaćenog općom i jamičastom korozijom. Budući da su vrijednosti brzine korozije od 0,01 do 0,048 $\mathrm{mm} \mathrm{god}^{-1}$, ugljični čelik se svrstava u skupinu postojanih materijala i obično je upotrebljiv u sustavima koji upotrebljavaju ispitivane vodene otopine. ${ }^{1}$

Utjecaj komercijalnog inhibitora na proces korozije ugljičnog čelika P235 u različitim vodenim otopinama; demineraliziranoj i/ili vodovodnoj vodi uz dodatak komercijalnog biocida ispitan je i elektrokemijskim metodama. Rezultati mjerenja potencijala otvorenog kruga ugljičnog čelika P235 tijekom jednog sata u različitim vodenim otopinama

Tablica 2 - Gubitak mase uzorka ugljičnog čelika P325 nakon 480 h izlaganja ispitivanim otopinama, brzina korozije i stupanj djelotvornosti inhibitora

\begin{tabular}{|c|c|c|c|}
\hline $\begin{array}{l}\text { Otopina } \\
\text { Solution }\end{array}$ & $\Delta m / g$ & $\mathrm{v} / \mathrm{mm} \operatorname{god}^{-1}$ & $\mathrm{z} / \%$ \\
\hline demineralizirana i vodovodna voda $(50: 50) \mathrm{s}$ biocidom & 0,0366 & 0,041 & - \\
\hline demineralizirana i vodovodna voda $(50: 50)$ s biocidom uz dodatak inhibitora & 0,0088 & 0,01 & 75,95 \\
\hline vodovodna voda s biocidom & 0,043 & 0,048 & - \\
\hline vodovodna voda s biocidom uz dodatak inhibitora & 0,0151 & 0,017 & 64,80 \\
\hline
\end{tabular}

Table 2 - P235 carbon steel weight loss after $480 \mathrm{~h}$ in examined solutions, corrosion rate and inhibiting efficiency 
prikazani su na slikama 9 i 10. U svim ispitivanim sustavima potencijal otvorenog kruga ugljičnog čelika P235 tijekom jednog sata postaje sve negativniji, a navedena promjena je najizraženija u otopinama bez inhibitora. Dodatak inhibitora uzrokuje pomak potencijala u smjeru pozitivnijih vrijednosti.

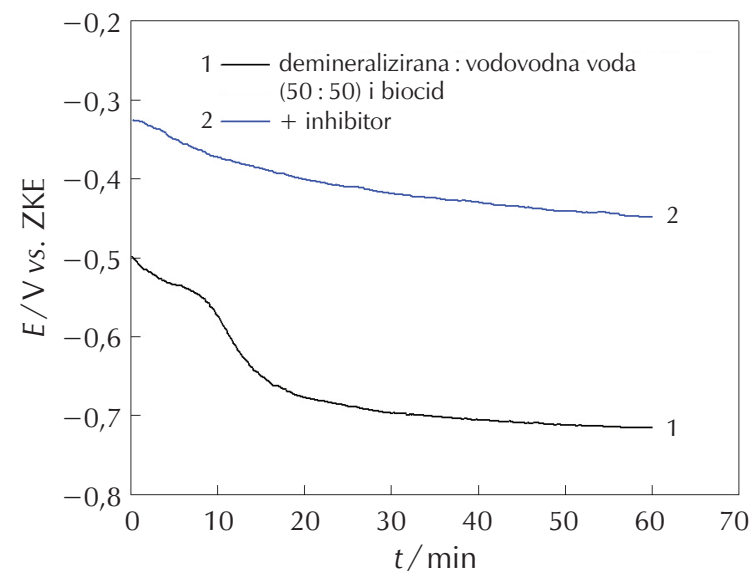

Slika 9 - Ovisnost potencijala otvorenog kruga ugljičnog čelika P235 u otopini demineralizirane i vodovodne vode (50 : 50) i biocida bez i uz dodatak inhibitora o vremenu

Fig. 9 - Evolution of the open circuit potential with time upon immersion of a P235 carbon steel in solution of demineralised and tap water (50:50) with biocide, and with or without addition of inhibitor

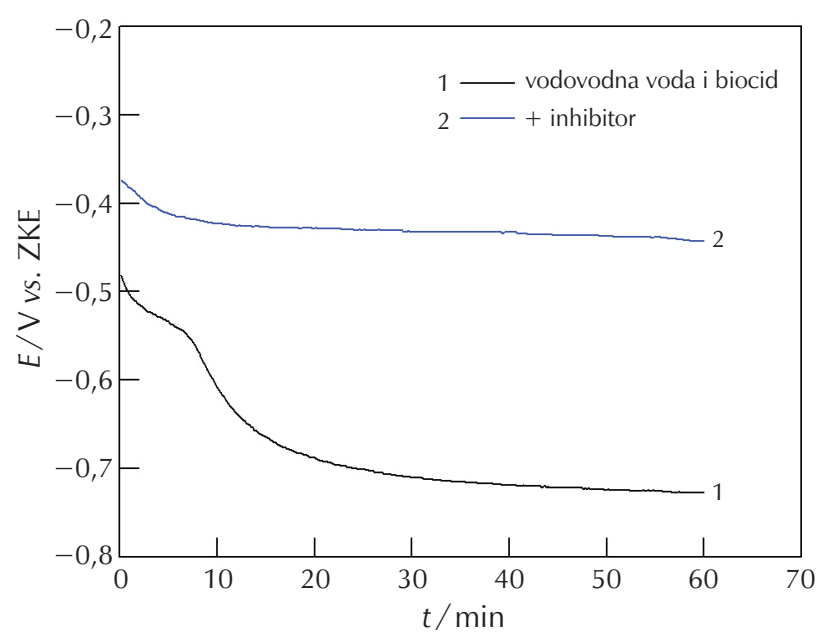

Slika 10 - Ovisnost potencijala otvorenog kruga ugljičnog čelika P235 u vodovodnoj vodi s biocidom bez i uz dodatak inhibitora o vremenu

Fig. 10 - Evolution of the open circuit potential with time upon immersion of a P235 carbon steel in tap water with biocide, and with or without addition of inhibitor

Na slikama 11 i 12 prikazani su rezultati dobiveni metodom linearne polarizacije ugljičnog čelika u ispitivanim otopinama u uskom području potencijala. Vidljivo je da su nagibi linearnih dijelova polarizacijskih krivulja veći za sustave s inhibitorom.

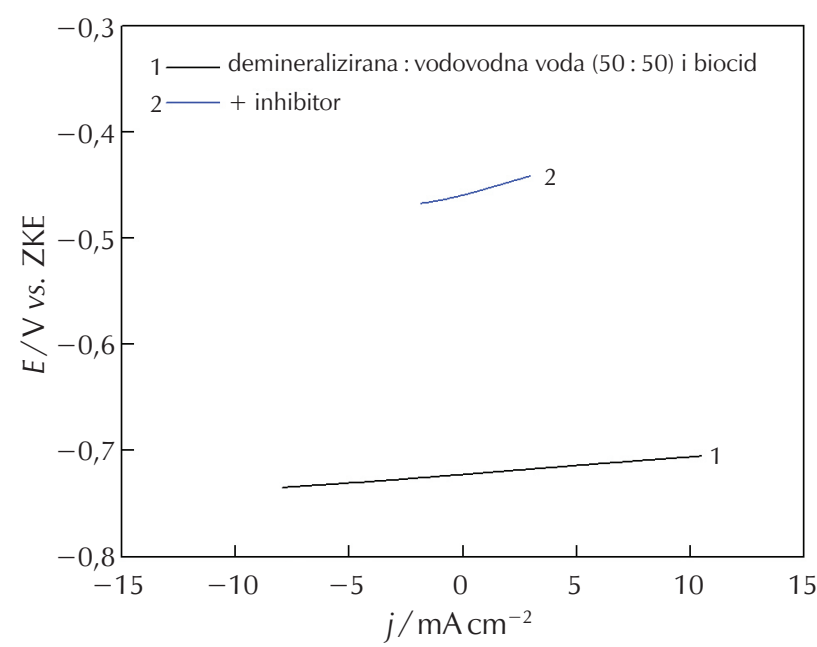

Slika 11 - Polarizacijske krivulje ugljičnog čelika P235 snimljene $1 \mathrm{~h}$ nakon uranjanja $\mathrm{u}$ otopinu demineralizirane $\mathrm{i}$ vodovodne vode (50:50) i biocida bez i uz dodatak inhibitora metodom linearne polarizacije

Fig. 11 - Linear polarisation curves for P235 carbon steel recorded after $1 \mathrm{~h}$ of immersion in solution of demineralised and tap water $(50: 50)$ with biocide, and with or without addition of inhibitor

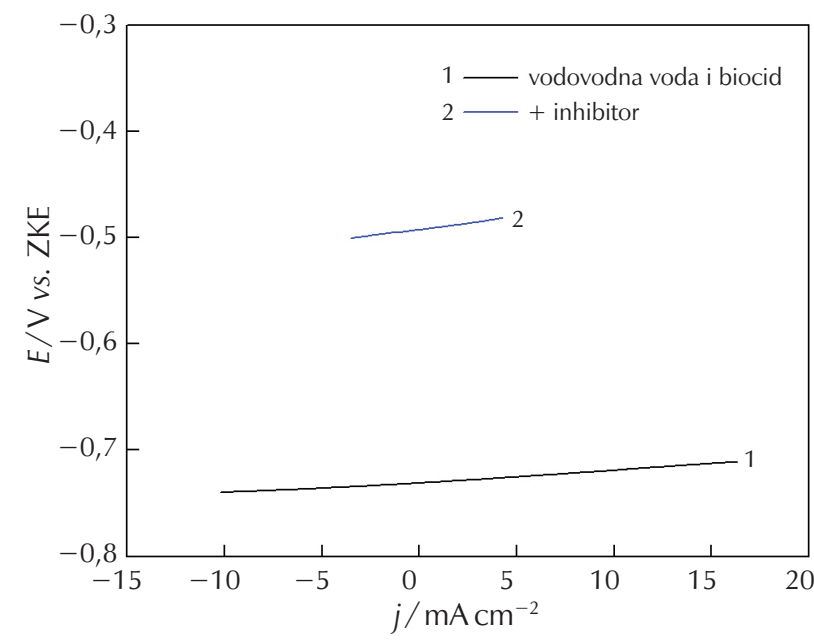

Slika 12 - Polarizacijske krivulje ugljičnog čelika P235 snimljene $1 \mathrm{~h}$ nakon uranjanja u vodovodnu vodu s biocidom bez dodatka i uz dodatak inhibitora metodom linearne polarizacije

Fig. 12 - Linear polarisation curves for P235 carbon steel recorded after $1 \mathrm{~h}$ of immersion in tap water with biocide, and with or without addition of inhibitor

Vrijednosti polarizacijskih otpora (tablica 3) određene su iz nagiba linearnih dijelova krivulja prema izrazu:

$$
R_{\mathrm{p}}=\frac{\Delta E}{\Delta j}
$$


Tablica 3 - Korozijski parametri određeni metodom linearne polarizacije

Table 3 - Corrosion paremeters obtained by linear polarization method

\begin{tabular}{|c|c|c|c|}
\hline $\begin{array}{l}\text { Otopina } \\
\text { Solution }\end{array}$ & $E_{\mathrm{kor}} / \mathrm{V}$ & $R_{\mathrm{p}} / \mathrm{k} \Omega \mathrm{cm}^{2}$ & $\mathrm{z} / \%$ \\
\hline demineralizirana i vodovodna voda $(50: 50)$ s biocidom & $-0,723$ & 1,641 & - \\
\hline demineralizirana i vodovodna voda $(50: 50)$ s biocidom uz dodatak inhibitora & $-0,459$ & 5,665 & 71,03 \\
\hline vodovodna voda s biocidom & $-0,731$ & 1,136 & - \\
\hline vodovodna voda s biocidom uz dodatak inhibitora & $-0,493$ & 2,356 & 51,78 \\
\hline
\end{tabular}

a stupanj djelotvornosti inhibitora izračunat je prema izrazu:

$$
\mathrm{z}=\frac{R_{\mathrm{pi}}-R_{\mathrm{p} 0}}{R_{\mathrm{pi}}} \cdot 100
$$

gdje je $R_{\mathrm{pi}}$ i $R_{\mathrm{p} 0}$ predstavljaju vrijednosti polarizacijskog otpora s inhibitorom i bez inhibitora.

Povećanje nagiba polarizacijskih krivulja znači povećanje polarizacijskog otpora. Budući da je polarizacijski otpor mjera otpornosti metala prema koroziji, slijedi to da što je on iznosom veći materijal je otporniji na koroziju.

Na slikama 13 i 14 prikazane su anodne i katodne krivulje polarizacije ugljičnog čelika u ispitivanim sustavima. Iz polarizacijskih krivulja metodom Tafelove ekstrapolacije određeni su korozijski parametri $\left(E_{\text {korr }} j_{\text {korr }} b_{\mathrm{k}}\right.$ i $\left.b_{\mathrm{a}}\right)$ koji su prikazani u tablici 4.

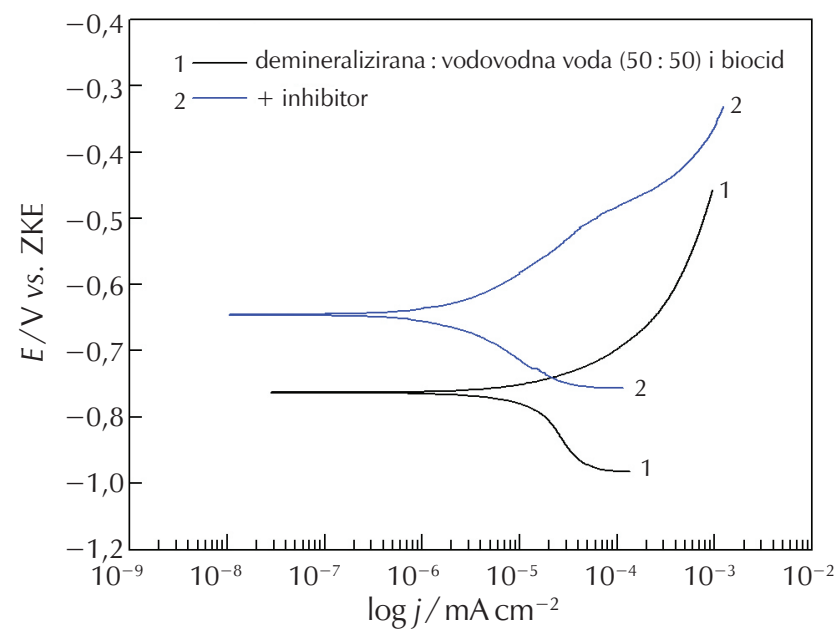

Slika 13 - Anodne i katodne krivulje polarizacije ugljičnog čelika P235 u otopinu demineralizirane i vodovodne vode (50 : 50) i biocida bez dodatka i uz dodatak inhibitora

Fig. 13 - Anodic and cathodic polarisation curves of P235 carbon steel in solution of demineralised and tap water (50:50) with biocide, and with or without addition of inhibitor

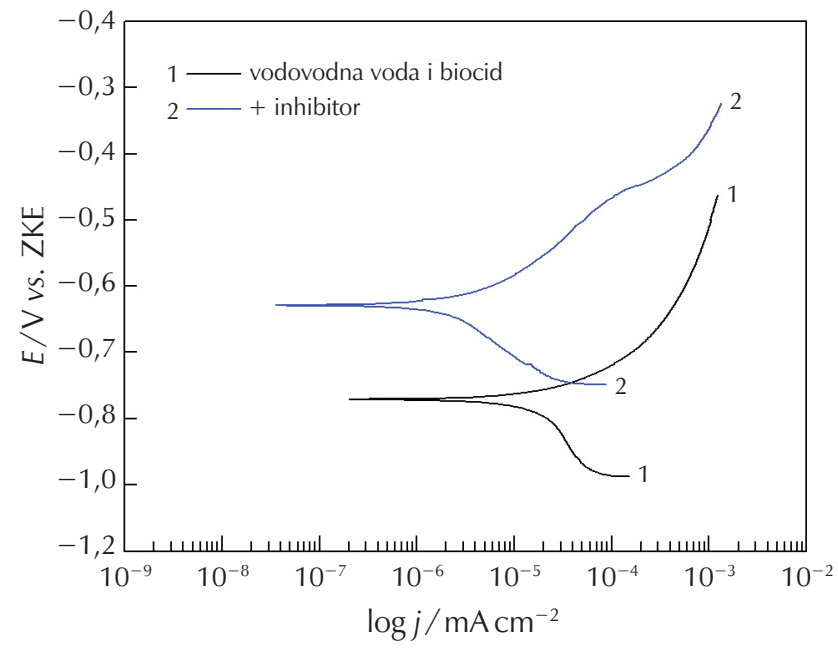

Slika 14 - Anodne i katodne krivulje polarizacije ugljičnog čelika P235 u vodovodnu vodu s biocidom bez njega i uz dodatak inhibitora

Fig. 14 - Anodic and cathodic polarisation curves of P235 carbon steel in tap water with biocide, and with or without addition of inhibitor

Stupanj djelotvornosti inhibitora izračunat je prema sljedećem izrazu:

$$
z=\frac{j_{0}-j_{i}}{j_{0}} \cdot 100
$$

gdje je $j_{0}$ gustoća korozijske struje u otopini bez inhibitora, a $j_{i}$ gustoća korozijske struje u otopini s inhibitorom.

Prikazani korozijski parametri ukazuju na to da dodatkom inhibitora dolazi do pomicanja korozijskog potencijala prema pozitivnijim vrijednostima, smanjuje se gustoća korozijske struje i smanjuje se brzina korozije. Iz tih opažanja moguće je zaključiti da komercijalni inhibitor pokazuje veći utjecaj na anodnu reakciju korozijskog procesa. Izračunate vrijednosti stupnja djelotvornosti potvrđuje i analiza površine uzorka pomoću optičkog mikroskopa pri povećanju $100 \times$ koja je provedena nakon potenciodinamičkih mjerenja (slike 15 i 16). Na snimkama površine uzorka ugljičnog čelika jasno su vidljiva korozijska oštećenja u obliku jamičaste korozije koja je manjeg razmjera u otopinama s inhibitorom. 
Tablica 4 - Korozijski parametri određeni metodom Tafelove ekstrapolacije Table 4 - Corrosion parameters obtained by Tafel extrapolation method

\begin{tabular}{l|c|c|c|c|c|c}
\hline $\begin{array}{l}\text { Otopina } \\
\text { Solution }\end{array}$ & $E_{\mathrm{kor}} / \mathrm{V}$ & $j_{\mathrm{kor}} / \mu \mathrm{Acm}$ & $b_{\mathrm{k}} / \mathrm{Vdec}^{-1}$ & $b_{\mathrm{a}} / \mathrm{V} \mathrm{dec}^{-1}$ & $\mathrm{z} / \%$ & $v / \mathrm{mm} \mathrm{god}^{-1}$ \\
\hline $\begin{array}{l}\text { demineralizirana i vodovodna voda }(50: 50) \mathrm{s} \\
\text { biocidom }\end{array}$ & $-0,719$ & 11,51 & $-0,394$ & 0,121 & - & 0,134 \\
\hline $\begin{array}{l}\text { demineralizirana i vodovodna voda }(50: 50) \mathrm{s} \\
\text { biocidom uz dodatak inhibitora }\end{array}$ & $-0,492$ & 1,89 & $-0,185$ & 0,182 & 83,57 & 0,022 \\
\hline $\begin{array}{l}\text { vodovodna voda s biocidom } \\
\text { vodovodna voda s biocidom uz dodatak inhibitora }\end{array}$ & $-0,737$ & 12,77 & $-0,201$ & 0,091 & - & 0,160 \\
\hline
\end{tabular}
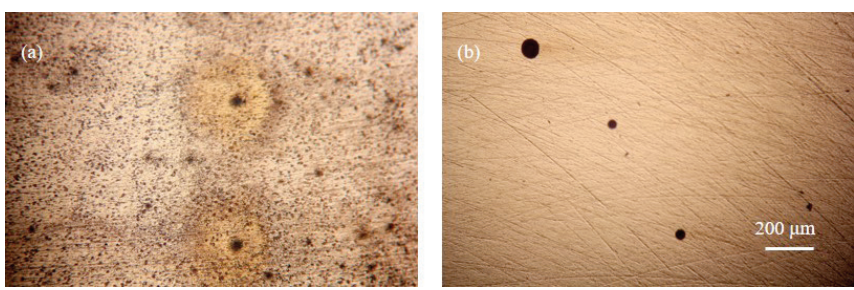

Slika 15 - Površina uzorak ugljičnog čelika P235 nakon potenciodinamičkih mjerenja u otopini demineralizirane i vodovodne vode $(50: 50)$ i biocida a) bez inhibitora i b) uz dodatak inhibitora snimljena pri povećanju $100 \times$

Fig. 15 - P235 carbon steel sample surface after potentiodynamic polarisation measurements in solution of demineralised and tap water (50:50) with biocide a) without inhibitor, b) with addition of inhibitor at $100 \times$ magnification
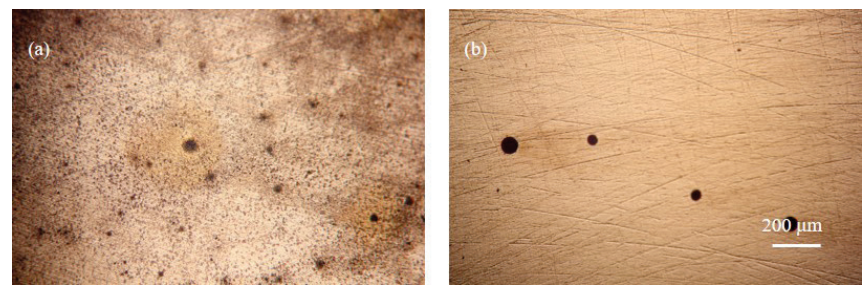

Slika 16 - Površina uzorak ugljičnog čelika P235 nakon potenciodinamičkih mjerenja u vodovodnoj vodi s biocidom a) bez inhibitora i b) uz dodatak inhibitora snimljena pri povećanju $100 \times$

Fig. 16 - P235 carbon steel sample surface after potentiodynamic polarisation measurements in tap water with biocide a) without inhibitor, b) with addition of inhibitor at $100 \times$ magnification

\section{Zaključak}

Gravimetrijska analiza pokazuje da ugljični čelik P235 korodira $\mathrm{u}$ ispitivanim vodenim otopinama, tj. $\mathrm{u}$ otopini demineralizirane $\mathrm{i}$ vodovodne vode $(50: 50)$ i biocida te $u$ vodovodnoj vodi s biocidom. Analizom površine ugljičnog čelika optičkim mikroskopom uočena je opća i jamičasta korozija, koja je bila izraženija u vodovodnoj vodi s biocidom. Dodatak komercijalnog inhibitora (Chemtec FI03) znatno smanjuje nastanak korozijskih oštećenja na površi- ni ugljičnog čelika u svim ispitivanim vodenim otopinama. Elektrokemijska ispitivanja pokazala su da je inhibitor visoke djelotvornosti i može se svrstati u anodne inhibitore. Rezultati istraživanja ukazuju na mogućnost primjene komercijalnog inhibitora u zaštiti ugljičnog čelika od korozije $\mathrm{u}$ ispitivanim vodenim otopinama. Također, s obzirom na opseg materijala zahvaćenog općom i jamičastom korozijom ugljični čelik se može svrstati u skupinu postojanih materijala i upotrebljiv je u sustavima u kojima se upotrebljavaju ispitivane vodene otopine i bez komercijalnog inhibitora.

\section{Popis kratica i simbola \\ List of abbreviations and symbols}

MIC - mikrobiološki poticana korozija

- microbially induced corrosion

w - maseni udjel, \%

- mass fraction, $\%$

$v \quad$ - brzina korozije, $\mathrm{mm} \mathrm{god}^{-1}$

- corrosion rate, $\mathrm{mm} \mathrm{god}^{-1}$

$m$ - masa, g

- mass, g

A - površina, $\mathrm{cm}^{2}$

- area, $\mathrm{cm}^{2}$

$t$ - vrijeme, $\mathrm{h}$

- time, $\mathrm{h}$

$\rho$ - gustoća, $\mathrm{g} \mathrm{cm}^{-3}$

- density, $\mathrm{g} \mathrm{cm}^{-3}$

z - inhibitorska djelotvornost, \%

- inhibiting efficiency, \%

b - nagib Tafelova pravca, $\mathrm{mV} \mathrm{dec}^{-1}$

- Tafel slope, $\mathrm{mV} \mathrm{dec}{ }^{-1}$

ZKE - zasićena kalomel elektroda

- saturated calomel electrode

$E_{\mathrm{ok}}$ - potencijal otvorenog strujnog kruga, $\mathrm{mV}$

- open circuit potential, $\mathrm{mV}$

$E_{\text {kor }}$ - korozijski potencijal, $\mathrm{mV}$

- corrosion potential, $\mathrm{mV}$

$R_{\mathrm{p}} \quad$ - polarizacijski otpor, $\mathrm{k} \Omega \mathrm{cm}^{2}$

- polarisation resistance, $\mathrm{k} \Omega \mathrm{cm}^{2}$

$j_{\text {kor }} \quad$ - gustoća korozijske struje, $\mu \mathrm{Acm}^{-2}$

- corrosion current density, $\mu \mathrm{A} \mathrm{cm}^{-2}$ 


\section{Literatura \\ References}

1. I. Esih, Z. Dugi, Tehnologija zaštite od korozije, Školska knjiga, Zagreb, 1990.

2. URL: http://www.grad.hr/nastava/hidrotehnika/gf/hidrotehnicke_gradevine/nastavni_materijali/Dio2/3_0_3_1_3_2.pdf (14. 5. 2020.).

3. H. H. Uhlig, Corrosion and Corrosion Control, $2^{\text {nd }}$ Ed., John Wiley \& Sons, 1963

4. N. Fredj, T. D. Burleigh, K. L. Heidersbach, B.R. Crowder, Corrosion of Carbon Steel in Waters of Varying Purity And Velocity, NACE - International Corrosion Conference Series. 5, 2012.

5. S. Takasaki, Y. Yamada, Effects of temperature and aggressive anions on corrosion of carbon steel in potable water, Corros. Sci. 49 (2007) 240-247, doi: https://doi.org/10.1016/j.corsci.2006.05.035.

6. A. D. Mercer, E. A. Lumbard, Corrosion of mild steel in water, Br. Corros. J. 30 (1995) 43-55, doi: https://doi.org/10.1179/ bcj.1995.30.1.43.

7. L. S. McNeill, M. Edwards, The Importance of Temperature In Assessing Iron Pipe Corrosion in Water Distribution Systems, Environ. Monit. Assess. 77 (2002) 229-2428, doi: https://doi.org/10.1023/A:1016021815596.

8. A. S. H. Makhlouf, M. A. Botello, Failure of the metallic structures due to microbiologically induced corrosion and the techniques for protection, u A. S. H. Makhlouf and M. Aliofkhazraei (ur.), Handbook of Materials Failure Analysis: With Case Studies from the Construction Industry, Elsevier Ltd. 2018., str. 1-18, doi: https://doi.org/10.1016/B978-008-101928-3.00001-X

9. D. J. Blackwood, An Electrochemist Perspective of Microbiologically Influenced Corrosion, Corros. Mater. Degrad. 1 (2020) 59-76, doi: https://doi.org/10.3390/cmd1010005.

10. I. B. Beech, J. Sunner, Biocorrosion: towards understanding interactions between biofilms and metals, Curr. Opin. Biotechnol. 15 (3) (2004) 181-186, doi: https://doi. org/10.1016/j.copbio.2004.05.001

11. R. Jia, T. Unsal, D. Xu, Y. Lekbach, T. Gu, Microbiologically influenced corrosion and current mitigation strategies: A state of the art review, Int. Biodeterior. Biodegradation 137 (2019) 42-58, doi: https://doi.org/10.1016/j.ibiod.2018.11.007.

12. H. C. Flemming, Biofouling and microbiologically influenced corrosion (MIC) - an economic and technical overview, u E. Heitz, W. Sand, H. C. Flemming (ur.), Microbial Deterioration of Materials. Springer-Verlag, Berlin-New York, 1996., str. 5-14.

13. G. A. Jacobson, Corrosion at Prudhoe Bay - A lesson on the line, Mater. Perform. 46 (2007) 26-34.

14. H. A. Videla, L. K. Herrera, Microbiologically influenced corrosion: looking to the future, Int. Microbiol. 8 (3) (2005) 169-80.

15. T. Gu, R. Jia, T. Unsal, D. Xu, Toward a better understanding of microbiologically influenced corrosion caused by sulfate reducing bacteria. J. Mater. Sci. Technol. 35 (2019) 631-636, doi: https://doi.org/10.1016/j.jmst.2018.10.026.

16. D. Enning, J. Garrelfs, Corrosion of iron by sulfate-reducing bacteria: new views of an old problem, Appl. Environ. Microb. 80 (2014) 1226-1236, doi: https://doi.org/10.1128/ AEM.02848-13.

17. J. Guan, L.-P. Xia, L.-Y. Wang, J.-F. Liu, J.-D. Gu, B.-Z. Mu, Diversity and distribution of sulfate-reducing bacteria in four petroleum reservoirs detected by using $16 \mathrm{~S}$ rRNA and dsrAB genes, Int. Biodeterior. Biodegrad. 76 (2013) 58-66, doi: https://doi.org/10.1016/j.ibiod.2012.06.021.

18. S. Chongdar, G. Gunasekaran, P. Kumar, Corrosion inhibition of mild steel by aerobic biofilm, Electrochim. Acta $\mathbf{5 0}$
(2005) 4655-4665, doi: https://doi.org/10.1016/j.electacta.2005.02.017.

19. H. da Costa Mattos, J. Reis, L. Paim, M. da Silva, R. L. Junior, V. Perrut, Failure analysis of corroded pipelines reinforced with composite repair systems, Eng. Fail. Anal. 59 (2016) 223236, doi: https://doi.org/10.1016/j.engfailanal.2015.10.007.

20. S. E. Coetser, T. E. Cloete, Biofouling and biocorrosion in industrial water systems, Crit Rev Microbiol. 31 (4) (2005) 213232, doi: https://doi.org/10.1080/10408410500304074.

21. J. D. Gu, Microbial biofilms, fouling, corrosion, and biodeterioration of materials, u Myer Kutz (ur.), Handbook of Environmental Degradation of Materials, William Andrew, Elsevier, Oxford, United Kingdom, 2018., str. 279-285.

22. URL: www.pbf.unizg.hr/content/download/33226/134627/ version/1/SKRIPTA2020.pdf (1. 5. 2020.).

23. D. Han, R. Jiang, Y. Cheng, Mechanism of electrochemical corrosion of carbon steel under deoxygenated water drop and sand deposit, Electrochim. Acta 114 (2013) 403-408, doi: https://doi.org/10.1016/j.electacta.2013.10.079.

24. L. Hongwei, M. Guozhuo, L. Weihua, G. Tingyue, L. Hongfang, Microbiologically Influenced Corrosion of Carbon Steel Beneath a Deposit in $\mathrm{CO}_{2}$-Saturated Formation Water Containing Desulfotomaculum nigrificans, Front. Microbiol. (2019), doi: https://doi.org/10.3389/fmicb.2019.01298.

25. G. V. Denisov, B. G. Kovrov, T. F. Kovaleva, Effect of the $\mathrm{pH}$ and Temperature of the Medium on the Rate of Oxidation of $\mathrm{Fe} 2+$ to $\mathrm{Fe} 3+$ by a Culture of Thiobacillus ferrooxidans and the Coefficient of Efficiency of Biosynthesis, Microbiology 50 (1981) 696-675.

26. T. V. Kovalenko, G. I. Karavaiko, V. P. Piskunov, Effect of Fe3+ Ions in the Oxidation of Ferrous Iron by Thiobacillus ferrooxidans at Various Temperatures, Microbiology 51 (1982) 142-148.

27. M. Nemati, C. Webb, A Kinetic Model for Biological Oxidation of Ferrous Iron by Thiobacillus ferrooxidans, Biotechnol. Bioeng. 53 (1997) 478-486, doi: https://doi. org/10.1002/(SICl)1097-0290(19970305)53:5<478::AIDBIT5>3.0.CO;2-E.

28. A. Okereke, S. E. Stevens Jr., Kinetics of Iron Oxidation by Thiobacillus ferrooxidans, Appl. Environ. Microbiol. 57 (1991) 1052-1056, doi: https://doi.org/10.1128/AEM.57.4.10521056.1991.

29. M. Finšgar, J. Jackson, Application of corrosion inhibitors for steels in acidic media for the oil and gas industry: A review, Corros. Sci. 86 (2014) 17-41, doi: https://doi.org/10.1016/j. corsci.2014.04.044.

30. Z. Tang, A review of corrosion inhibitors for rust preventative fluids, Curr. Opin. Solid State Mater. Sci. 23 (4) (2019) 100759, doi: https://doi.org/10.1016/j.cossms.2019.06.003.

31. R. Martinez Palou, O. Olivares-Xomelt, N. V. Likhanova, Environmentally Friendly Corrosion Inhibitors, u M. Aliofkhazraei (ur.), Developments in Corrosion Protection, InTech, 2014, doi: https://doi.org/10.5772/57252.

32. B. E. Amitha Rani, Bharathi Bai J. Basu, Green Inhibitors for Corrosion Protection of Metals and Alloys: An Overview, Int. J. Corros. 2012 (2012), doi: https://doi. org/10.1155/2012/380217.

33. B. Morris, G. Kraan, Application of Biocides and Chemical Treatments to Both Combat Microorganisms and Reduce (Bio)Corrosion, u T. L. Skovhus, D. Enning, J. S. Lee (ur.) Microbiologically Influenced Corrosion in the Upstream Oil and Gas Industry, 2017., str. 229-254, doi: https://doi. org/10.1201/9781315157818-12.

34. G. Joka, Biocidi (biocidni proizvodi) jučer, danas, sutra? Kem. Ind. 67 (2018) 470-472. 


\section{EXTENDED ABSTRACT \\ Investigation of Effects of Inhibitor on Corrosion of Carbon Steel in Water with Biocide

\author{
Ivana Smoljko, Ladislav Vrsalović, Senka Gudić, and Klara Đaković
}

The effect of a commercial inhibitor (Chemtec Fl30) on the corrosion of P235 carbon steel in water (demineralised and/or tap water) with the addition of a commercial biocide (Chemtec BI01) was studied in the present work. This study was carried out by weight loss and electrochemical methods, while specimen's surface was examined using optical microscope.

Results obtained from gravimetric measurement revealed that P235 carbon steel corroded in aqueous solution, i.e., in a solution of demineralised and tap water (50:50) and a biocide (Fig. 1), and in tap water with a biocide (Fig. 5). By analysing the surface of carbon steel with an optical microscope, general and pitting corrosion was observed, which was more pronounced in tap water with biocide (Figs. 2 and 6). The addition of a commercial inhibitor significantly reduced the occurrence of corrosion damage on the surface of carbon steel (Figs. 3, 4, 7, and 8) and decreased the rate of carbon steel corrosion in all aqueous solutions (Table 1).

Electrochemical investigations performed by open circuit potential measurement, linear polarisation and potentiodynamic polarisation measurement showed that the inhibitor Chemtec FIO3 shifted the potential to more positive values (Figs. 9 and 10), increased polarisation resistance (Table 3), decreased the rate of carbon steel corrosion, and had high efficiency in all tested solutions (Table 4).

The results obtained showed that this commercial inhibitor could be used as an effective inhibitor for the corrosion of carbon steel in aqueous media.

\section{Keywords}

Carbon steel, corrosion, inhibitor, biocide, weight loss and electrochemical methods

University of Split

Faculty of Chemistry and Technology

Department of Electrochemistry and

Materials Protection

Ruđera Boškovića 35

21000 Split, Croatia
Original scientific paper

Received May 30, 2020

Accepted July 7, 2020 